\title{
A postal survey of effluent generation and disposal in the Zimbabwean dairy industry
}

\author{
Daniel IO Ikhu-Omoregbe* and Husiel Masiiwa \\ Department of Chemical Engineering, National University of Science and Technology, Bulawayo, Zimbabwe
}

\begin{abstract}
Water is a major utility in the dairy industry, which results in significant effluent volumes being generated, hence the challenge of its disposal cannot be ignored. In Zimbabwe, industry generally is not made to pay the full cost of managing industrial effluents, which inadvertently encourages environmental pollution. This paper presents the results of a postal survey of effluent generation and disposal by the dairy industry. A total of 30 questionnaires were sent out to various milk processors around the country out of which 15 were returned. The useful respondents receive and process $56 \%$ of the total milk produced in the country. The data obtained indicated that while some of the plants discharge their effluents into the municipal sewers, others discharge theirs by means of land irrigation. This latter method has the consequence of groundwater pollution. Respondents' knowledge of effluent characteristics was generally low, which is not surprising as there are no stringent penalties for polluting.
\end{abstract}

\section{Introduction}

Milk produced on the dairy farms in Zimbabwe is sold to the dairyprocessing industries for conversion into milk products. Some of the milk farmers have small on-site plants, which process some of their milk into various products. From a production level of less than $150 \times 10^{6} \mathrm{I}$ at independence in 1980 , milk production peaked at $270 \times 10^{6} \mathrm{I}$ in 1991 resulting in the country satisfying local demand with some surplus for export. However, the period after the drought of 1992 has been characterised by a decline in milk production such that production level was $175 \times 10^{6} \mathrm{I}$ in 1999 (Zimbabwe Quarterly Digest, 2000). Eighty per cent (80\%) of the milk produced is sold through the Dairibord Zimbabwe Limited (formerly the Dairy Marketing Board) which has processing plants in the major cities.

The volume of effluent arising in a dairy plant is dependent on two factors, the type of dairy product being processed and the degree of water management being exercised and thus the amount of water being conserved. For example, cheese, milk powder and evaporating plants generate larger volumes of effluent than those producing pasteurised milk. According to Hiddink (1990), the water-to-milk ratios for liquid-milk-processing plants in some European countries range between 0.5 to $12.9 \mathrm{l} \cdot \mathrm{kg}^{-1}$ of milk. In view of the increased cost of water and effluent treatment, any reduction in water consumption is essential. Milk and related products have very high chemical oxygen demand, COD values (milk: 218000 mg. $\left.\right|^{-1}$; skimmed milk: $100000 \mathrm{mg} \cdot \mathrm{I}^{-1}$; whey: $80000 \mathrm{mg} \cdot \mathrm{l}^{-1}$ ). The sources of effluent in the dairy industry include cleaning of equipment, washing away of product leakage and floors and contaminated and returned products by customers, which are discarded into the drains. The average COD for dairy effluents in the USA was given as $3800 \mathrm{mg} \cdot \mathrm{l}^{-1}$ (Jones, 1974) and that for South Africa was suggested to be similar (Strydom et al., 1993). That for the Zimbabwean dairy industry was given as $3300 \mathrm{mg} \cdot \mathrm{l}^{-1}$ (IkhuOmoregbe et al., 2001) which is similar to the above published data.

Like in most process industries, the dairy industry has effluent disposal problems. This problem is acute in Zimbabwe due to the

* To whom all correspondence should be addressed.

酒(263 9) 464304/475192; fax: (263 9) 286803;

e-mail: dikhuomoregbe@hotmail.com

Received 30 July 2001; accepted in revised form 26 February 2002. absence of stringent control of effluent disposal by process industries. Under the Urban Councils Act of 1995, industries could discharge any amount of effluent into the municipal sewage system provided the quality of the effluents is below prescribed limits as set by the city by-laws. Enforcement of these by-laws was not only poor, penalties imposed were not stringent enough to force a change of habit (Jarawaza, 1997). Furthermore, most industries do not pretreat their effluents before discharge into the municipal sewers (IkhuOmoregbe et al., 2001).

The purpose of the postal survey is to ascertain the state of effluent production and disposal by the dairy industry in Zimbabwe and its findings are presented in this paper. It is hoped that the results will throw light on effluent management in the Zimbabwean dairy industry and highlight the need for pretreatment at the individual plant level.

\section{Method}

A questionnaire was designed and sent to 30 milk buyers whose addresses could be obtained from the National Dairy Society of Zimbabwe. The questionnaire sought information from respondents in the following areas:

- volume of milk received

- types of dairy products produced

- volume of water used in production

- types of chemical used in the particular factory

- the volume and characteristics of effluents generated

- treatment of effluent before disposal

- method(s) of effluent disposal

- cost of effluent disposal

- expressed interest in effluent studies.

The questionnaire was such that respondents were required to give an average daily value of specific parameters. These included water usage, milk reception and effluent discharge volume. These values were then converted to yearly rates by multiplying by a factor of 300 , assuming a 300 working-day year as most of the respondents work $6 / 7 \mathrm{~d}$ a week. The 30 milk buyers included the main manufacturers and distributors of fresh milk and dairy products in the country as well as the smaller dairy plants, some of which are located at the farms. The questionnaires were sent to each dairy 


\begin{tabular}{|c|c|c|c|c|}
\hline \multicolumn{5}{|c|}{$\begin{array}{c}\text { TABLE } 1 \\
\text { Results obtained for Group } 1 \text { (smaller dairies) }\end{array}$} \\
\hline & $\begin{array}{c}\text { Management } \\
\text { knowledge }\end{array}$ & Minimum & Maximum & Average \\
\hline $\begin{array}{l}\text { Effluent volumes, } \\
\mathrm{kl} \cdot \mathrm{yr}^{-1}\end{array}$ & $85.7 \%$ & 36 & 976.5 & 237 \\
\hline $\begin{array}{l}\text { Pollution values } \\
\text { pH } \\
\text { Temp., } \mathrm{T}^{\circ} \mathrm{C} \\
\text { COD }\end{array}$ & $28.6 \%$ & $\begin{array}{l}5.5 \\
20 \\
\text { n.a. }\end{array}$ & $\begin{array}{l}7.2 \\
25 \\
\text { n.a. }\end{array}$ & $\begin{array}{l}6.35 \\
22.5 \\
\text { n.a. }\end{array}$ \\
\hline $\begin{array}{l}\text { Disposal costs } \\
\mathrm{Z} \$ \cdot \mathrm{yr}^{-1}\end{array}$ & $20.0 \%$ & $\mathrm{Z} \$ 24000$ & $\mathrm{Z} \$ 24000$ & $\mathrm{Z} \$ 24000$ \\
\hline $\begin{array}{l}\text { Water usage } \\
\mathrm{kl} \cdot \mathrm{yr}^{-1}\end{array}$ & $85.7 \%$ & 15 & 5400 & 1084 \\
\hline Product losses \% & $71.4 \%$ & $0.31 \%$ & $0.63 \%$ & $0.50 \%$ \\
\hline
\end{tabular}

\section{Group 1}

This group represents the smaller dairies, which are mostly situated on the dairy farms. Most of the respondents indicated pasteurised milk as their main products. Other products such as sour milk, yoghurt, fresh cream, butter and cheese are mostly produced on request. Milk reception volumes varied between $0.12 \mathrm{kl} \cdot \mathrm{d}^{-1}$ and 3.25 $\mathrm{kl} \cdot \mathrm{d}^{-1}$ with an average of $0.79 \mathrm{kl} \cdot \mathrm{d}^{-1}$.

The results show that six out of the seven respondents in this group demonstrated some knowledge of their effluent volumes while 2 or $28.6 \%$ of the respondents had knowledge of their effluent characteristics, Table 1 . However, only values for the $\mathrm{pH}$ and temperature were provided and none gave any other pollution parameter such as COD. The effluent volumes reported by these respondents varied between 36 and $975 \mathrm{kl} \cdot \mathrm{yr}^{-1}$ with an average value of 237 $\mathrm{kl} \cdot \mathrm{yr}^{-1}$. Five of the respondents in this group dispose of their effluent by land irrigation, one into a septic tank and the other through feeding

industry with a reply self-addressed stamped envelope for easy and early reply. Also included was a letter explaining the purpose of the exercise. The respondents were allowed a month to return the completed questionnaire but this had to be extended to allow for more replies. Despite this some of the critical respondents had to be followed up, as their feedback was considered essential to a meaningful outcome of the exercise. Furthermore, two large dairy factories were visited in both Bulawayo and Harare to familiarise ourselves with some of the processes involved in the dairy industry and to obtain insight into the sources of effluents in the plants.

\section{Results}

The response rate of our survey report was $50 \%$, from which two of the 15 responses were considered as spoilt papers (one was returned blank and the other had insufficient useful information). The useful respondents represented $47 \%$ of the total sent out and these respondents process about $56 \%$ of the total milk produced in Zimbabwe based on 1999 figures as obtained from the Zimbabwean Quarterly Digest of Statistics, March 2000. This means that the respondents include the major players in the Zimbabwean dairy industry. The level of response compares well with a similar survey in South Africa (Strydom et al., 1993). A satisfactory response of $29.6 \%$ of those surveyed was reported and these were said to process $70 \%$ of the total milk produced in 1990 in South Africa. It must be emphasised that the dairy industry in Zimbabwe is much smaller than that in South Africa and effluent generation and disposal are still very sensitive issues amongst industrialists.

Based on the volume of milk processed the respondents were classified into two groups as follows:

- Group 1: Milk reception less than $10 \mathrm{kl} \cdot \mathrm{d}^{-1}$ (7 respondents)

- Group 2: Milk reception greater than $10 \mathrm{kl} \cdot \mathrm{d}^{-1}$ (6 respondents).

While most of the smaller respondents (Group 1) produce between 1 to 3 products, the larger respondents (Group 2) produce a number of different products. The results of the survey, reflecting management knowledge of effluent volumes, pollution potentials of the effluents and cost of effluent disposal, are presented below. of chicken. One of the respondents indicated using a filter bed to treat effluent prior to disposal. One of the respondents reported expenditure associated with effluent disposal of about Z\$24000 as a yearly average. There was not much enthusiasm amongst this group as only two respondents indicated interest in future effluent treatment projects while one would like to have a biogas plant to run his/her dairy.

Figures 1 and 2 show the product losses and water consumption in relation to the volume of milk received or processed respectively. The product losses from this group varied between 0.3 and $0.6 \%$. Water consumption varied between $15 \mathrm{kl} \cdot \mathrm{yr}^{-1}$ and $5400 \mathrm{kl} \cdot \mathrm{yr}^{-1}$ giving an average consumption of $1084 \mathrm{kl} \cdot \mathrm{yr}^{-1}$ for the group. There appears to be no direct correlation between the amount of milk processed and the quantity of water utilised. For example that which produces $186 \mathrm{kl} \cdot \mathrm{yr}^{-1}$ uses $5400 \mathrm{kl}$ of water a year while that which claims to process $976.5 \mathrm{kl} \cdot \mathrm{yr}^{-1}$ uses $15 \mathrm{kl}$ of water and another which processes about $240 \mathrm{kl}$ of milk uses $450 \mathrm{kl}$ of water a year. This gives a specific water intake (water consumption to raw milk) ratio of between 0.015 and 29.0 which does not agree with some published data (Hiddink,1990). This inconsistency is mostly due to lack of adequate records of water usage by members in this group rather than it being due to the type of products produced as they produce mostly similar products.

\section{Group 2}

This group represents the larger dairies, which are mostly situated in the cities. As it was for Group 1, pasteurised milk was the most common product. Other products include UHT milk, sterilised milk, low fat milk, sour milk, condensed milk, milk powder, cheese, fresh cream, butter, buttermilk, yoghurt and cultured cream. Only one of the respondents produces powdered milk. Table 2 shows the obtained results for this group. Milk reception for this group varied from $12 \mathrm{kl} \cdot \mathrm{d}^{-1}$ to $132 \mathrm{kl} \cdot \mathrm{d}^{-1}$ giving an average of 49.5 $\mathrm{kl} \cdot \mathrm{d}^{-1}$. Two $(33 \%)$ of the six respondents gave values for their effluent volumes and these were 10500 and $30000 \mathrm{kl} \cdot \mathrm{yr}^{-1}$ respectively. This gives an average of $20250 \mathrm{kl} \cdot \mathrm{yr}^{-1}$ with these two respondents. Only one respondent indicated effluent characteristics, that is $\mathrm{pH}$, temperature and suspended solids and did not provide value for COD. Four of the respondents in this group dispose of their effluents into municipal sewers, one into a pond and the other 


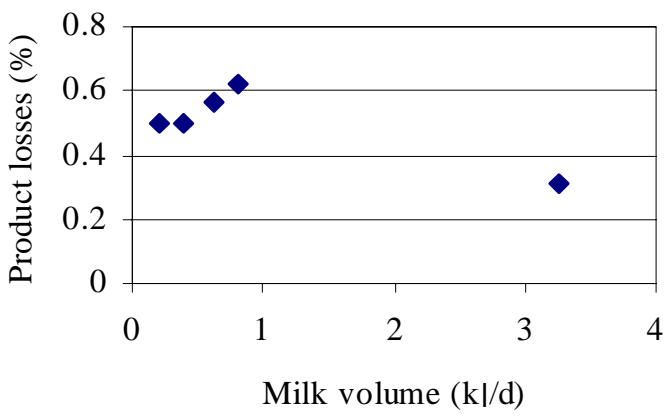

Figure 1

Product losses expressed as percentage of the raw milk volume received (Group 1)

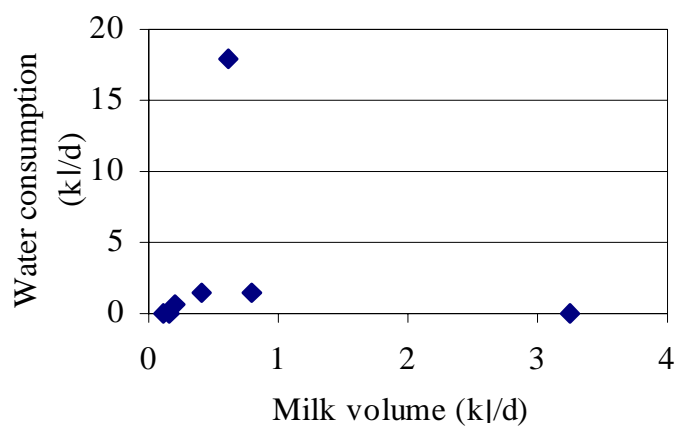

Figure 2

Comparison of water consumption and raw milk volume ratios (Group 1)

through irrigation. One of the respondents indicated dilution as an effluent pretreatment method prior to disposal. Two respondents in this group reported expenditure associated with effluent disposal which, on the average represented a yearly total of $Z \$ 622860$ and the other Z\$960 000. All respondents indicated interest in future effluent treatment projects, with one already implementing an environmental policy.

Figures 3 and 4 show the product losses and water consumption in relation to the volume of milk received or processed respectively. The reported product losses varied between 0.1 and $2.5 \%$. Water consumption by this group varied between $20 \mathrm{kl} \cdot \mathrm{d}^{-1}$ and $240 \mathrm{kl} \cdot \mathrm{d}^{-1}$ with an average value of $120.5 \mathrm{kl} \cdot \mathrm{d}^{-1}$. Again we do not find a direct correlation between water usage and amount of milk processed. The highest water consumption of $240 \mathrm{kl} \cdot \mathrm{d}^{-1}$ respondent receives/ processes $80 \mathrm{kl} \cdot \mathrm{d}^{-1}$ and that consuming 200 $\mathrm{kl} \cdot \mathrm{d}^{-1}$ receives $132 \mathrm{kl} \cdot \mathrm{d}^{-1}$. The specific water intake ratio is between 1.15 and 6 which corresponds with the figures published in the literature.

\begin{tabular}{|c|c|c|c|c|}
\hline \multicolumn{5}{|c|}{$\begin{array}{c}\text { TABLE } 2 \\
\text { Results obtained for Group } 2 \text { (larger dairies) }\end{array}$} \\
\hline & $\begin{array}{c}\text { Management } \\
\text { knowledge }\end{array}$ & Minimum & Maximum & Average \\
\hline $\begin{array}{l}\text { Effluent volumes } \\
\mathrm{kl} \cdot \mathrm{yr}^{-1}\end{array}$ & $33.3 \%$ & 10500 & 30000 & 20250 \\
\hline $\begin{array}{l}\text { Pollution values } \\
\text { pH } \\
\text { Temp., } \mathrm{T}^{0} \mathrm{C} \\
\text { COD }\end{array}$ & $33.3 \%$ & $\begin{array}{l}6.8 \\
45 \\
\text { n.a. }\end{array}$ & $\begin{array}{l}9.0 \\
45 \\
\text { n.a. }\end{array}$ & $\begin{array}{l}7.9 \\
45 \\
\text { n.a. }\end{array}$ \\
\hline $\begin{array}{l}\text { Disposal costs } \\
\mathrm{Z} \$ \cdot \mathrm{yr}^{-1}\end{array}$ & $33.3 \%$ & $\mathrm{Z} \$ 622860$ & $Z \$ 960000$ & Z\$791430 \\
\hline $\begin{array}{l}\text { Water usage } \\
\mathrm{kl} \cdot \mathrm{yr}^{-1}\end{array}$ & $100.0 \%$ & 6900 & 72000 & 36150 \\
\hline Product losses\% & $66.7 \%$ & 0.04 & 2.50 & 0.73 \\
\hline
\end{tabular}

\section{Discussion}

Although the response level was only $47 \%$, it is considered significant in that this represented $56 \%$ of all milk received and processed in Zimbabwe. This level of response is thought to be due to the sensitive nature of the subject matter. Furthermore, as some of the respondents include some of the major dairy industries in Zimbabwe, the information gathered from this survey could be said to be a fair representation of the effluent-handling practice within the industry. Most of the respondents either had no knowledge of or refused to disclose the physico-chemical characteristics or volumes of their effluents due perhaps to the sensitive nature of industrial effluents. With the low level of awareness of the effluent characteristics from their establishment, it is therefore not surprising that environmental issues will not be a priority. This attitude is thought to be due significantly to the industrial effluent management scenario in Zimbabwe.

In Zimbabwe, the industrial effluent management policy is such that the polluter can discharge his waste into the municipal sewers with little or no consequence to the polluter. In most cases any volume could be discharged provided the quality of these effluents is within the prescribed limits (Nyoni, 1999). Evidence available indicates that industrial effluent monitoring by municipal authorities is poor so that quite a number of industries flout these standards regularly (Ikhu-Omoregbe et al., 2001). The pollution control system existing in Zimbabwe is such that the system is entirely financed by government with the nation as a whole bearing the financial cost of environmental damage and pollution control system (ZINWA, 1998). It is therefore not surprising to observe the rather low level of awareness of management of dairy industries about the properties of their effluents. However, in recent times some urban councils have either begun or are in the process of implementing new legislation known as "The Polluter Pays Principle". Under this law, each industry will be placed in one of three bands namely green, yellow and red with green being the least polluting and red the most polluting band. Council officials are expected to visit each factory to establish the effluent characteristics and hence the license fees for a permit to discharge such an effluent into the municipal sewers. Additional penalties are imposed whenever the limits allowed under the permit are exceeded. It is hoped that this will compel industries to become more concerned about the impact of their effluents on the environment and take steps for on-site pretreatment before discharge into municipal sewers.

The smaller dairies represented by Group 1 use land irrigation as their method for effluent disposal, which can result in aquifer pollution. Other disposal methods used by members in this group were septic tank or chicken feed. The larger dairies, Group 2, 


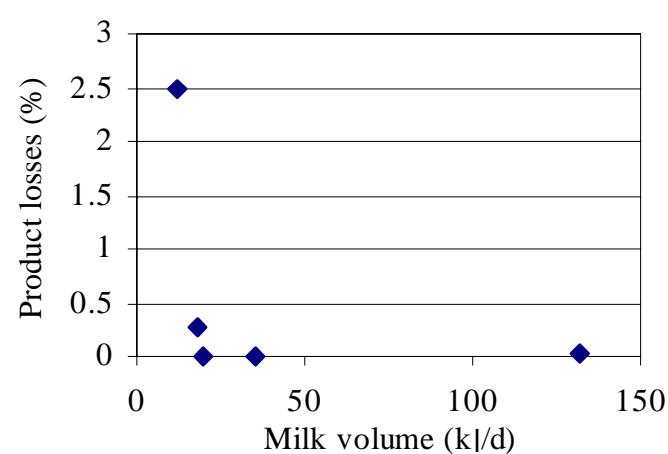

Figure 3

Product losses expressed as a percentage of the raw milk volume received (Group 2)

generally discharge their effluents into municipal sewers, and thus pay some disposal costs though insignificant under the current waste management Acts. However, some of the respondents were observed to pay as much as $\mathrm{Z} \$ 1 \times 10^{6} \cdot \mathrm{yr}^{-1}$. Only one respondent in this group indicated irrigation as a disposal method while another uses a pond.

Effluent pretreatment in both groups is minimal, confirming the dairy industry's tolerance of the current situation and due to the reasons given earlier for lack of awareness. The results, Figure 3, suggest that respondents in Group 2, i.e. the larger dairies, show better control of product losses with only one respondent operating above $0.5 \%$. According to Hiddink (1990), product losses could vary between 0.5 to $2.0 \%$ suggesting that milk processors in this country operate rather efficiently. A similar survey for South Africa (Strydom et al., 1993) reported losses as high as 7\%.

The specific water consumption of a dairy industry is the amount of water used in processing one liter of fresh milk. The values reported in the literature vary from 0.5 to $20 \mathrm{l} \cdot \mathrm{kg}^{-1} \mathrm{milk}$ processed while Hiddink (1990) gave amounts of 0.5 to $3.0 \mathrm{I}$ as being acceptable. Strydom et al. (1993) in their report observed that South African dairies were consuming excessive amounts of water as values of up to $6.0 \mathrm{I} \cdot \mathrm{kg}^{-1}$ milk processed for cultured products were reported. In this report respondents in Group 1 gave water consumption below $5.0 \mathrm{kl} \cdot \mathrm{d}^{-1}$ regardless of milk consumption. For example, one respondent that receives 620 I of raw milk per day indicated a water consumption of $180 \mathrm{kl} \cdot \mathrm{d}^{-1}$ while that which receives 3255 I of milk per day indicated a water consumption of $50 \mathrm{I}$. This suggests that the respondents were either over- or underestimating or simply just guessing their water consumption figures, rather than due to discrepancies arising from the type of products. Both of the above two respondents produce rather similar products.

For respondents in Group 2, the larger dairies there appear to have increasing water consumption with milk volume processed due to the type of products produced. The water estimates from this group are thought to be more accurate when compared to Group 1 since water is a major overhead which is closely monitored and controlled in larger industries in order to reduce or control production costs. The specific consumption values of 1.15 and 6.0 fall within published values. Only two of the respondents are outside the range suggested by Hiddink (1990).

Better water management will result in savings where effluent is discharged at high cost. Where effluents are used for irrigation, improved product loss control will reduce the negative impact on soil condition. Even though dairy effluents may have some fertilising effect and may not contain serious toxic substances, irrigation is considered objectionable as complexing agents and detergents may mobilise heavy metals in the soil and groundwater.

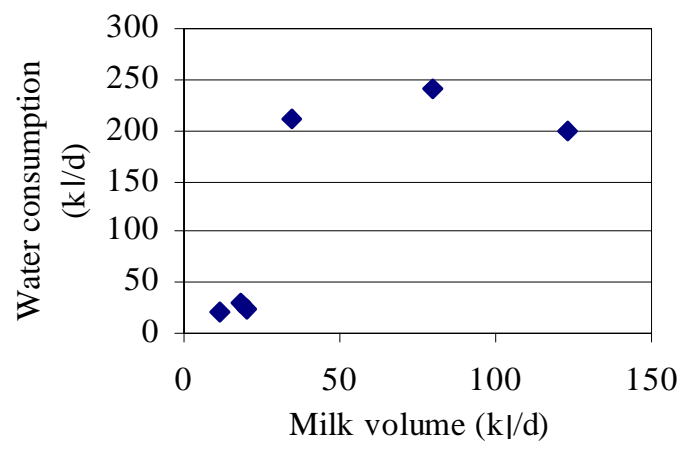

Figure 4

Comparison of water consumption and raw milk volume ratios (Group 2)

\section{Conclusion}

The results of this survey are valuable to the dairy industry given the increasing interest and debate on the preservation of our environment and reduction and control of industrial pollution. The results give an insight into the effluent management in the Zimbabwean dairy industry. This is significant as most urban councils are in the process of introducing the polluter-pays-principle for their industrial effluent and sewage management.

Most of the large dairies in Zimbabwe discharge their effluents into municipal sewers while the smaller operators use their effluents for irrigation, which could impact negatively on the soil and groundwater condition. The larger dairies show better water management of water but are poor performers with respect to product losses. The level of awareness of effluent characteristics and the impact thereof on the environment by operators of the Zimbabwean dairies leave a lot to be desired. This lack of awareness cannot be explained by the presupposition that effluents from the dairy have a minimal effect on the environment. Industrialists should be aware of the environmental impact of their processes and take steps to minimise these effects. It is therefore encouraging to observe that quite a number of respondents expressed interest in participating in programs on effluent production and disposal in the future.

\section{References}

HIDDINK J(1990) Friends of the environment. Overview from a processor's perspective. In: Proc. $23^{\text {rd }}$ Int. Congress 2 803-813.

IKHU-OMOREGBE DIO, KUIPA PK and NYONI V (2001) Industrial liquid effluent monitoring and disposal in Bulawayo, Zimbabwe A Review. Proc. $6^{\text {th }}$ World Congr. of Chem. Eng., Melbourne, Australia.

JARAWAZA M (1997) Water Quality Monitoring in Harare. In: Moyo, NAG (ed.) Lake Chivero - A Polluted Lake. Univ. of Zimbabwe Publications. 27-34.

JONES HR (1974) Pollution control in the dairy industry. Pollution Technology Review No. 7. Published in the USA by Noyes Data Corporation, Park Ridge, New Jersey.

NYONI VS (1999) Some proposed aspects of water quality management in Bulawayo in the New Millenium. Paper presented at NORAD Workshop on Water Quality and Conservation, Kadoma, Zimbabwe.

STRYDOM JP, MOSTERT JF and BRITZ TJ (1993) Effluent production and disposal in the South African dairy industry: A postal survey. Water SA 19 (3) 253-258.

ZIMBABWE NATIONAL WATER AUTHORITY (ZINWA) (1998) Operational Guidelines for the Control of Water Resource Pollution in Zimbabwe.

ZIMBABWE QUARTERLY DIGEST OF STATISTICS (2000) March. 